Received 25 July 2020

Accepted 18 December 2020

Link to DOI:

10.25220/WNJ.V05.i1.0007

Journal Website:

www.worldnutrijournal.org

\section{The potential of seaweed salt as an alternative low sodium salt: safety and sensory test}

Lindarsih Notowidjojo, ${ }^{1}$ Purwantyastuti Ascobat, ${ }^{2}$ Saptawati Bardosono, ${ }^{1}$ Jana Tjahjana Anggadiredja $^{3}$

1. Department of Nutrition, Faculty of Medicine, Universitas Indonesia-Cipto Mangunkusumo Hospital, Jakarta

2. Department of Pharmacology, Faculty of Medicine, Universitas Indonesia-Cipto Mangunkusumo Hospital, Jakarta

3. Lecturer of Natural Resources, National Resilience Institute, Republic of Indonesia. Chairman of Indonesian Seaweed Society

\begin{abstract}
Background: Indonesia is one of the largest producers of red seaweed in the world, but there is very little research done on the role of red seaweed in the health sector. This study is about red seaweed type Euchema cottoni and it's potential as seaweed salt that has lower sodium and rich in other minerals.

Methods: This research was divided into two phases and conducted from December 2016 to March 2017. The first phase is a safety analysis in terms of metal, mold and bacteria contamination of seaweed from three different places of Indonesia: Saumlaki, Maluku; Nusa Dua, Bali and Flores, Nusa Tenggara Barat. After the seaweed safety was selected, the seaweed was made into powder at Industrial Research and Development Agency (BPPT), Tangerang. The seaweed powder mixed with ordinary salt with four type of concentrations were subjected to a salty sensory test by nine panellists who have been working at the food production at Hospital for at least one year. The second phase was to do acceptance sensory test of the seaweed salt product taste against a concentration that was selected in first phase to first-degree hypertensive subjects aged 25-59 years by using soup as the meal-media. Chi-square test was used to analyse the difference.

Results: Seaweed from Saumlaki, Maluku was selected as the safest seaweed due to its lowest content of metal, mold and bacterial contaminations. The ratio of seaweed powder to ordinary salt powder 1:1 was selected by nine panellists in salty sensory test. Analysis of minerals from the seaweed salt product found that besides the lower sodium and iodine content, it's potassium and magnesium content were much higher than ordinary salt. Salty taste test by 62 respondents with first degree hypertension with age 25-59 years showed no significant difference in saltiness between seaweed salt and ordinary salt.

Conclusions: In conclusion, the seaweed salt product with a 1:1 ratio to ordinary salt powder is safe and acceptable to be used as an alternative low sodium salt.

Keywords Euchema cottoni, seaweed salt, salty sensory test
\end{abstract}

Corresponding author:

Lindarsih Notowidjojo

Department of Nutrition, Faculty of Medicine,

Universitas Indonesia-Cipto Mangunkusumo Hospital,

Jl. Salemba Raya no.6, Central Jakarta, Indonesia

Email:linnoto@yahoo.com

\section{Introduction}

Red seaweed which is widely available in Indonesia is Eucheuma cottonii. ${ }^{1}$ Seaweed contains minerals of more than $36 \%$ dry weight with calcium $(\mathrm{Ca})$ and magnesium (Mg) and iodine (I) as its main 
minerals. ${ }^{2,3} \mathrm{Na}$ levels in seaweed is generally low around $2-3 \%$, while the $\mathrm{K}$ content is around 5-6\% . ${ }^{3}$ $\mathrm{Na}$ content in seaweed is around 1.87 grams per 100 grams and $\mathrm{K}$ content is around 5.87 grams per 100 grams. Thus, the $\mathrm{Na} / \mathrm{K}$ ratio is about 0.32 . Some studies suggest that low sodium may reduce blood pressure. ${ }^{4,5}$ High $\mathrm{K}$ intake is also said to be inversely related to the incidence of hypertension. ${ }^{5}$ Recommendations from WHO and European Society of Hypertension/European Society of Cardiology: Guidelines for the Lifestyle Management to Reduce Cardiovascular Risk for $\mathrm{Na}$ intake is $2-2.4$ grams per day (equivalent to 5-6 grams of salt per day). ${ }^{6,7,8}$ Recommendations from WHO for K intake of at least 3,51 grams per day. ${ }^{9}$ The composition of $\mathrm{Na}$ and $\mathrm{K}$ in seaweed is thought to be beneficial as an antihypertension in mild hypertension. ${ }^{10}$

Indonesian Basic Health Research 2013 and 2018 showed hypertension prevalence in Indonesian adults increased from $25.8 \%$ to $34.1 \%,{ }^{11,12}$ while data from the Basic Health Research 2007 and 2013 revealed that Indonesian population aged over 10 years consume high daily salt. ${ }^{11,13}$

Seaweeds also contain peptides which have angiotensin converting enzyme inhibiting (ACE-I) activity that may play a role in overcoming hypertension. ${ }^{10,14}$ Other nutrients contained in seaweed are fibres with a greater percentage of water-soluble fibres, fatty acids (eicosapentaenoic and arachidonic acids), some vitamins ( $\mathrm{B}_{12}, \mathrm{C}$, and E), and carotenoids that have antioxidant activity. 2,10,15 Efforts to reduce salt intake are constrained because salt substitute products with low $\mathrm{Na}$ content in Indonesia are very limited. Research on the nutrient contents, the role of seaweed and its benefits for health is still limited, especially in Indonesia. ${ }^{16}$

The objective of this study is to analyse the safety of seaweed salt product and to test its saltiness taste as compared to the ordinary salt, to be used as an alternative to reduce blood pressure among mild hypertension subjects.

\section{Methods}

The research method was divided into two phases. In the first phase, Eucheuma cottonii seaweed from three regions: Saumlaki, Maluku; Nusa Dua Bali and Flores, West Nusa Tenggara were tested for safety from metal contamination at the Analysis and Calibration Laboratory, Center for Agro Industry, Industry Research and Development Agency, Bogor, and safety testing from bacterial contamination at the Industrial Research and Development Agency (BPPT), Tangerang. After obtaining the ethic approval and ethic license from Harapan Kita Hospital and Ethics Committee of the Medical Faculty, Universitas Indonesia, Eucheuma cottonii seaweed powder from the region with the lowest contamination was made and produced at BPPT, Tangerang. Seaweed that had been cleaned, cut about two or three $\mathrm{cm}$, pasteurized, then grind with $0.5 \mathrm{~mm}$ disc mill, filtered, to produce seaweed powder. Furthermore, the seaweed powder is mixed with ordinary salt with a concentration of $1: 2,2: 3$, $1: 1$ and $3: 2$, then salty sensory test was performed to compare those four different concentrations of seaweed salt to the ordinary salt. The test was conducted in the food production department of Hospital, at east Jakarta from December 2016 to March 2017.

The salty sensory test panel consist of healthy nine panelists aged 18 to 59 years, who have worked for at least one year in the food production department at a hospital. The panelists were asked to taste the soup $(200 \mathrm{ml})$ mixed with the 3 gram of seaweed salt and did the salty sensory test that was mostly similar to soup $(200 \mathrm{ml})$ mixed with 3 grams of ordinary salt. The subjects were asked to drink plain water, every time after they tasted the soup. The subjects were asked to taste and compare both soups and did the salty sensory test, from most similar to soup with ordinary salt. Values from not similar (1) to more than ordinary salt (5). Sensory test results were used to determine the concentration that would be used in phase two. Mineral contents of both seaweed salt product and ordinary salt were analysed at Sucofindo Laboratory. The second phase was the savoury test of the chosen seaweed salt product taste against ordinary salt by using soup as the meal-media to 62 first-degree hypertensive or mild hypertension subjects aged 25-59 years. Subjects aged 25-59 years are recruited due to subjects age 25 and above are independent and can plan their own diet while the oldest age of 59 years to reduce the possibility of deterioration of taste and organ function with increasing age. 


\section{Results}

Eucheuma cottonii seaweed from three regions: Saumlaki, Maluku; Nusa Dua Bali and Flores, West Nusa Tenggara went through safety testing from metal contamination at the Analysis and Calibration Laboratory, Center for Agro Industry, Industry Research and Development Agency, Bogor and safety testing from bacterial contamination at BPPT, Tangerang. The analysis test results of metal and bacterial contamination in Table 1 showed that seaweed originating from Saumlaki Island, Maluku, is the best one in meeting safety requirements. Seaweed powder was made at BPPT, Tangerang. The process of pasteurization was chosen to reduce the number of bacteria, to maintain the nutritional value of seaweed and decrease water content of seaweed to $10-12 \%$.

\section{Mixing seaweed powder and ordinary salt ${ }^{\circledR}$}

First step, the quantity of seaweed powder in gram mixed with quantity of ordinary salt in gram was calculated based on literature study. The conversion values of sodium chloride and salt was as follows: $40 \% \mathrm{Na}$ and $60 \% \mathrm{Cl}$. Whereas 1 gram of $\mathrm{Na}$ with 2.6 grams of salt and $1 \mathrm{mmol} \mathrm{Na}$ is equal to $23 \mathrm{mg}$ of $\mathrm{Na}$ and according to literature studies, $\mathrm{Na}$ content in seaweed is around $2-3 \%$ dry weight. ${ }^{3}$

Four different ratios of seaweed powder and ordinary salt that have sodium content below 2 gram as WHO recommendation ${ }^{6}$, were tested for sensory salty test. The ratio were 1:2 (A), 2:3 (B), 1:1 (C) and $3: 2$.(D) which contained sodium of: 1.58 grams, 1.44 grams, 1.23 grams and 1.04 grams consecutively.

The results of the salty sensory test from a ninemember panelist, the soup with type $\mathrm{C}$ product was the most closely palatable and nice compared to soup with ordinary salt. Therefore, in the second phase of the research formula type $\mathrm{C}$ was used: 3 grams of seaweed powder and 3 grams of ordinary salt.

Samples of seaweed salt and ordinary salt used in the study were examined for their Sodium, Potassium, Magnesium and Iodine content at Sucofindo Laboratory (Table 2). Sodium and iodine levels in seaweed salt are lower and potassium and magnesium levels are higher than ordinary salt.
The second phase was the sensory salty and acceptance test of the seaweed salt product against ordinary salt by using soup as the meal-media to 62 first-degree hypertensive or mild hypertension subjects aged 25-59 years old.

The same amount of seaweed salt and ordinary salt were sprinkled on two bowls clear chicken soup. The result is shown in Table 3, which indicates there is no significant differences found in the salty taste tests of seaweed salted soup and ordinary salted soup (Chi-square test, $\mathrm{p}=0.332$ ).

\section{Discussion}

Seaweed Eucheuma cottonii harvested from Saumlaki, Maluku was selected, due to it's lowest metal, mold and bacterial contamination compared to those from Nusa Dua, Bali and Flores, NTB. The purpose of this research is to study the potential of seaweed powder as an alternative salt function, so the safety criteria refer to guideline of iodized salt for consumption from the National Standardization Agency (BSN) in $2016^{17}$. The criteria are as follows: metal contamination in miligram/kilogram dry weight: lead $(\mathrm{Pb})$ less than 10 , cadmium $(\mathrm{Cd})$ less than 0.5 , mercury $(\mathrm{Hg})$ less than 0.1 , arsenic (As) less than 0.1 , In the safety guidelines for iodized salt products, there is no standardization for contamination of tin ( $\mathrm{Sn})$, mold and bacteria. Safety criteria for contamination of tin $(\mathrm{Sn})$, mold and bacteria refer to the guidelines commonly used in France. ${ }^{2,15}$ France quality criteria for edible seaweed for tin (Sn) less than $5 \mathrm{mg} / \mathrm{kg}$ dry matter, and for mold and bacterial contamination in colony unit/gram: coliform less than 10, anaerobic less than 100. Seaweed from Saumlaki contained cadmium (Cd) less than 0.5 and has smallest mold contamination. This due to Saumlaki's location is in the Maluku islands, where the beach is still very quiet, the population is sparse, and the sea coast is clean and relatively low in pollution compared to the coast of Nusa Dua, Bali and Flores, NTB.

The sensory salty test results selected ratio of 1 : 1, that was 3 grams of seaweed powder and 3 grams of ordinary salt, the most closely palatable and nice compared to soup using ordinary salt. Ratio of seaweed powder to ordinary salt 1:2 and 2:3 was less salty and ratio 3:2 was too salty. Six gram of selected seaweed salt ratio contained $\mathrm{Na}: 1,23 \mathrm{mg}$ compare 
to ordinary salt contains Na: 2.28 gr. Na of seaweed salt is lower than ordinary salt and is safer in preventing hypertension.

The salt powder was then analysed for $\mathrm{Na}, \mathrm{K}, \mathrm{Mg}$ and Iodine minerals in the Sucofindo Laboratory. The content of sodium in seaweed salt is around $24.15 \%$ and ordinary salt is around $37.6 \%$. Six gram of seaweed salt contained Na:1.45 gr. Sodium levels appear to be higher than the initial count of about $17 \%$, this is because the water content is very different. In the literature study, the data used were dry seaweed materials with water content around 20$30 \%$, while seaweed powder around $10-12 \%$, due to pasteurization process. Potassium and Magnesium levels in seaweed salt are much higher than ordinary salt. Potassium content of seaweed salt was $4 \%$, while ordinary salt was only $0,03 \%$. Magnesium content of seaweed salt was $0,16 \%$ and ordinary salt was only $0,002 \%$. Iodine content of seaweed salt in the form of $\mathrm{KIO} 3$ is lower than ordinary salt, because ordinary salt products that are used and are on the market was fortified with iodine. Since the standard of Iodine requirement is $30 \mathrm{mg}$ per $\mathrm{kg}^{17}$, then this salt is not recommended for people with iodine deficiency.

The second phase, sensory salty taste test was done to compare and to evaluate the acceptance of seaweed salt with ordinary salt using clear chicken soup as media to 62 first-degree hypertensive or mild hypertension subjects aged 25-59 years old. There were 8 respondents who said that the saltiness of seaweed salted soup was sufficient and tasty compared to 13 respondents who said that the salty taste of ordinary salted soup was sufficient and tasty. After being tested statistically with the Chi-square test it was found there was no significant differences $(p=0.332)$. Eight subjects who chose seaweed salted soup as tasty, comment that soup taste more savory than ordinary salted soup. Taste of seaweed powder was revealed as ocean-like: minerally and salty, fishy taste and has umami flavors. ${ }^{18,19}$ Seaweed powder mix with ordinary salt would have salty taste and umami flavor, that was acceptable and nice by the subjects.

In conclusion, the seaweed salt product with a $1: 1$ ratio to ordinary salt powder is safe and acceptable to be used as an alternative low $\mathrm{Na}$ salt 
Table 1. Analysis of seaweed metal and bacterial contamination from Saumlaki, Nusa Dua and Flores

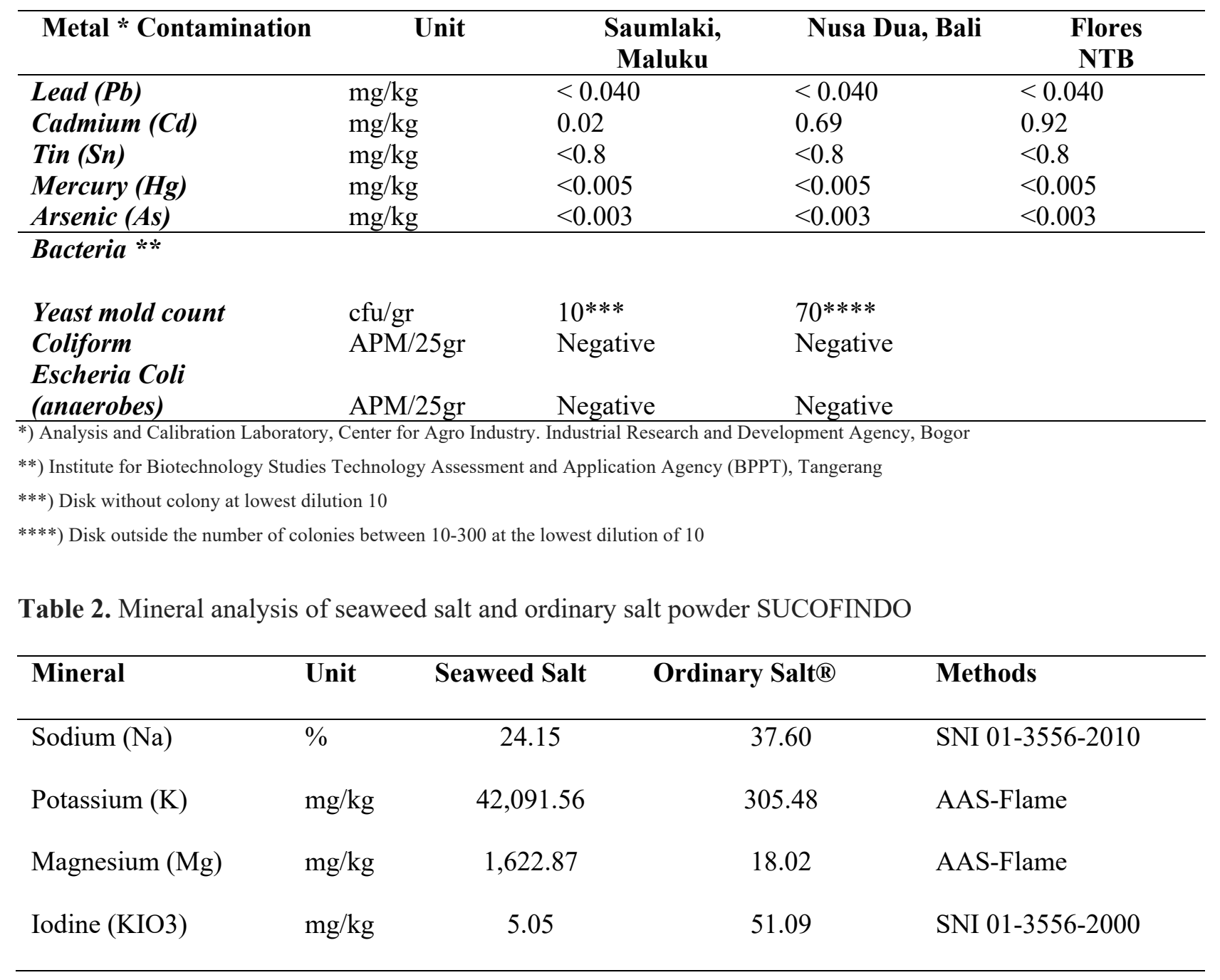

Table 3. Salty sensory tests of seaweed salt and ordinary salt

\begin{tabular}{|c|c|c|c|c|c|}
\hline Variable & $\begin{array}{c}1 \\
\text { Not salty }\end{array}$ & $\begin{array}{c}2 \\
\text { Slightly salty }\end{array}$ & $\begin{array}{c}3 \\
\text { Less salty }\end{array}$ & $\begin{array}{c}4 \\
\text { Same/enough } \\
\text { salty }\end{array}$ & $\begin{array}{c}5 \\
\text { Too salty }\end{array}$ \\
\hline Seaweed salt & & 16 & 31 & 8 & 7 \\
\hline $\begin{array}{l}\text { Ordinary } \\
\text { salt } \AA\end{array}$ & & 8 & 4 & 13 & 37 \\
\hline
\end{tabular}

Chi-square test, $\mathrm{p}=0.332$ 


\section{Conflict of Interest}

Authors declared no conflict of interest regarding this article.

\section{Open Access}

This article is distributed under the terms of the Creative Commons Attribution 4.0 International Licence

(http://creativecommons.org/licenses/by/4.0/), which permits unrestricted use, distribution, and reproduction in any medium, provided you give appropriate credit to the original author(s) and the source, provide a link to the Creative Commons license, and indicate if changes were made.

\section{References}

1. Armita D. Analisis Perbandingan Kualitas Air di Daerah Budidaya Rumput Laut dengan Daerah Tidak Ada Budidaya Rumput Laut, di Dusun Malelaya, Desa Punaga, Kecamatan Mangarabombang, Kabupaten Takalar. Makassar: Universitas Hasanuddin 2011.

2. Burtin P. Nutritional Value of Seaweeds. Electron J Environ Agric Food Chem. 2003;2:4.

3. Mulyono N. HRA. Kandungan Nutrisi Dalam Rumput Laut EUCHEUMA dari Indonesia (Nutrient Content In Eucheuma Seaweed From Indonesia). Personal communication 2016.

4. Lewington S, Clarke R, Qizilbash N, Peto R, Collins R. Age-specific relevance of usual blood pressure to vascular mortality: a meta-analysis of individual data for one million adults in 61 prospective studies. Lancet 2002;360:1903-13.

5. Sacks FM, Svetkey LP, Vollme WM, et al. Effects on blood pressure of reduced dietary sodium and the Dietary Approaches to Stop Hypertension (DASH) diet. DASH-Sodium Collaborative Research Group. N Engl J Med. 2001;344:3-10.

6. World Health Organization Guideline: Sodium intake for adults and children. World Health Organization, Geneva, Switzerland 2012.

7. Mancia G, Fagard R, et al. 2013 ESH/ESC Guidelines for the Management of Arterial Hypertension. TheTask Force for the management of arterial hypertension of the European Society of Hypertension (ESH) and of the European Society of Cardiology (ESC). Journal of
Hypertension

2013;31:1281-1357.

http://www.jhypertension.com.

8. Eckel RH, dkk. 2013 AHA/ACC Guideline on Lifestyle Management to Reduce Cardiovascular Risk. A Report of the American College of Cardiology/American Heart Association Task Force on Practice Guidelines. Circulation 2014;129:S76-S99.

9. WHO Guideline: Potassium Intake for adults and children. World Health Organization, Geneva, Switzerland 2012.

10. Cardoso SM, Pereira OR, Seca AML, et al. Seaweed as Preventive Agents fo Cardiovascular Disease: From Nutrients to Functional Foods. Ar.Drugs 2015;13:68386865. DOI:10.3390/md13116838.

11. Health Research and Development Agency. Basic Health Research 2013. Ministry of Health, Republic of Indonesia 2014

12. Health Research and Development Agency. Basic Health Research 2018. Ministry of Health, Republic of Indonesia 2018.

13. Health Research and Development Agency. Basic Health Research 2007. Ministry of Health, Republic of Indonesia 2008.

14. Cha SH, Lee KW, Jeon YJ. Screening of Extracts from Red Algae in Jeju for Potentials Marine Angiotensin - I Converting Enzyme (ACE) Inhibitory Activity. Algae 2006;21:343-8.

15. Holdt SL and Kraan S. Bioactive Compounds in Seaweed: Functional Food Applications and Legislation. J Appl Phycol. 2011;23:543-597. DOI:10.1007/s10811-010-9632-5.

16. Suparmi AS. Mengenal Potensi Rumput Laut: Kajian Pemanfaatan Sumber Daya Rumput Laut dari Aspek Industri dan Kesehatan. 2009; XLIV.

17. Badan Standardisasi Nasional. Garam Konsumsi Beriodium, Standar Nasional Indonesia (SNI 3556:2016). Jakarta 2016.

18. The Taste Project. From https://www.cybercolloids.net/sites/default/files/TAST E.pdf

19. Bruno J, What Does Seaweed Taste Like? January 25, 2019. From: https://thrivecuisine.com/taste-test/whatdoes-seaweed-taste-like 